\title{
ENCIGA: 25 ANOS PUBLICANDO E VIVINDO CIENCIA EN GALEGO
}

Paulino Estévez

Presidente de Enciga 

Vou facer, en primeiro lugar, unha presentación da Asociación dos Ensinantes de Ciencias de Galicia (ENCIGA). ENCIGa é unha asociación sen ánimo de lucro que ten entre os seus fins a mellora da calidade do ensino na área das ciencias. Fundada o 16 de xaneiro de 1988, é basicamente unha asociación de profesores que tentan enriquecer a súa formación para conseguir unha mellora na calidade do ensino na área de ciencias, en todos os niveis educativos. $\mathrm{Na}$ súa estrutura toma como modelo outras asociacións, fundamentalmente a ASE (Association for Science Education) inglesa e a NTSA (National Teachers Scientific Association) americana.

Cos seus máis de 650 socios, ENCIGA é a asociación de profesorado máis numerosa de Galicia. Entre as asociacións de profesores de ciencias é a máis veterana do Estado español e unha das máis veteranas de Europa.

Para conseguir o seu obxectivo fundamental tenta impulsar e dinamizar os traballos de investigación educativa e intercambio de información entre os asociados tendo como medios para acadalo: o congreso anual, o Boletín das Ciencias e reunións e conferencias ocasionais.

O congreso de ENCiga é o acontecemento anual da asociación que, ademais do fin formativo, terá un fin claramente social: o achegamento e intercambio de experiencias entre todos os asistentes. Lévanse realizado vinte e tres congresos, aos que asisten ao redor de 350 profesores de Galicia, Portugal, do resto de España e tamén, en menor medida, doutros países europeos. Debido ao número de socios portugueses -e como recońecemento á súa participación durante moitos anos na asociación-, no ano 2006 celebrouse o xix Congreso en Póvoa de Varzim. Este ano o XXIv Congreso de ENCIGA terá lugar no IEs Fontem Albei da Fonsagrada os días 17, 18 e 19 de novembro de 2011. Os congresos constan de conferencias plenarias, relatorios orais de 30 minutos de duración, obradoiros de 90 minutos e sesións de pósters. Cando a ocasión o require, realízanse mesas redondas con varios relatores e un posterior debate. Nos tres últimos congresos -no Carballiño, Silleda e Narón- presentáronse, en total, 185 comunicacións e pasaron polos congresos máis de 1000 persoas.

Unha parte importante das actividades da nosa Asociación está relacionada co estudo, divulgación e investigación de métodos que acheguen a ciencia á sociedade e ao alumnado de diferentes niveis, o que amosa que o profesorado ten un interese especial por conseguir a máxima competencia do alumnado galego nas materias da área de Ciencias. O promover o uso do galego nas publicacións 
de ámbito científico e ao mesmo tempo na aula é unha mostra dese intento de achegar a Ciencia á sociedade galega.

O Boletín das Ciencias é o medio de comunicación oficial de Enciga. Todos os resultados, informacións, artigos de actualidade, etc., tanto dos grupos de traballo como dos socios, canalízanse a través del. A día de hoxe, publicáronse 73 números. Ao longo de todos estes anos, nos 73 números publicados da revista e nos 23 congresos realizados, case todas as publicacións do boletín e das comunicacións dos congresos foron presentadas en galego, o que demostra que é unha lingua tan natural e tan boa coma calquera outra para transmitir e divulgar ideas científicas. Estamos convencidos de que non hai razóns para deixar de usar o galego para falar e escribir de ciencia. O Boletín das Ciencias pretende ser unha revista áxil e con reflexos. Publicáronse varios números extraordinarios do Boletín das Ciencias: en maio de 1998 abordouse o tema da minaría do cobre e analizouse o desastre de Aznalcóllar (25 de abril de 1988); en maio de 2003 publicouse un número extraodinario dedicado integramente ao desastre do Prestige, que se analizaba desde diversos puntos de vista: económico, do dereito do mar, ecolóxico, etc.; o número 60 de xuño de 2006 foi outro monográfico dedicado ao lume e que foi premonitorio dos lumes que ese mesmo verán devastarían Galicia. No número 72 do mes de abril de 2011 abórdase, como non podía ser doutro xeito, o accidente de Fukushima. Os últimos extraordinarios publicados son: un, o número 67 de marzo de 2009, dedicado a Mendeleev co gallo do 150 aniversario da publicación en 1869 da primeira táboa periódica; e outro, o número 70, que é un monográfico de Física. Neste último hai que destacar a colaboración do alemán Jack Steinberger (Nobel de Física en 1988) e do americano Sheldon Lee Glashow (Nobel de Física en 1979).

En xaneiro do ano 2008 puidemos traer ao suízo Richard Ernst (Nobel de Química en 1991) para dar unha extraordinaria conferencia que abriou a todos os que tiveron a sorte de poder asistir a ela. Deixounos unha carta-misiva con algúns consellos e dirixida aos mozos estudantes galegos. Este manuscrito aparece no último número publicado do Boletín das Ciencias.

ENCIGA participou, por representación, en todos aqueles congresos, xornadas, simposios, reunións, etc. aos que foi invitada para explicar canto se recolle nestas liñas. 


\section{UN POUCO DE HISTORIA}

Un colectivo de profesores, dos distintos niveis do ensino, reuníronse no ano 1987 para botar a andar a idea de constituír un grupo de traballo interdisciplinar e preocupado pola mellora da calidade docente.

Xa desde un principio, pensouse na publicación dun boletín, que tivese certa periodicidade e que tratase temas tan variados como: historia da ciencia, presentación de prácticas de laboratorio, saídas de campo ou pola cidade pensando sobre temas de interese na aula, ensaios sobre temas de difícil comprensión polo alumnado, ensaios sobre temas de actualidade -o desastre de Aznalcóllar, o Prestige ou o accidente nuclear en Fukushima son exemplos diso-, foros sobre temas de actualidade -os produtos transxénicos, o xenoma, as novas enerxías-, biografías de científicos relevantes, comentarios sobre exposicións ou eventos destacados...

As nosas publicacións van dirixidas ao profesorado de ciencias dos tres niveis de ensino e a nosa principal área xeográfica de distribución é Galicia, aínda que temos presenza doutras e noutras partes do Estado e de Portugal. O Boletín das Ciencias recibe orixinais que veñen doutras partes do territorio español e do estranxeiro -Portugal, Bélxica, Cuba, Arxentina, etc.- e distribúese ás sociedades de ciencias do Estado español e ás bibliotecas da área de ciencias e pedagoxía das tres universidades galegas.

Desde o punto de vista económico, contribúen de xeito esporádico a Xunta de Galicia, as deputacións e mais os concellos para axudar a financiar as actas dos congresos, a recepción inaugural e algúns complementos, pero sobrevivimos coa cota que pagamos cada un dos asociados e co traballo desinteresado de toda a Directiva. Cómpre pedir en moitas instancias e solicitar moitas axudas, pero vivimos co noso sen depender de ninguén.

Cando xurdiu a asociación, naceu tendo como un dos motivos principais a defensa da nosa fala. Nunca houbo debate sobre o tema, pois naceu coa decisión de expresarnos en galego. Toda a nosa vida é en galego. A lingua oficial é o galego e cando nos enviaron traballos ou comunicacións en castelán, inglés ou outras linguas solicitóuselles permiso aos autores para traducilos ao galego. $\mathrm{Na}$ actualidade, se o autor non indica o contrario, tradúcense automaticamente ao galego para publicalos.

Nacemos co pensamento de vivir en galego e seguimos a vivir en galego.

Para máis información: www.enciga.org 